\title{
Front Matter: Volume 10040
}

, "Front Matter: Volume 10040," Proc. SPIE 10040, Endoscopic Microscopy XII, 1004001 (11 April 2017); doi: 10.1117/12.2268483

SPIE. Event: SPIE BiOS, 2017, San Francisco, California, United States 


\title{
PROGRESS IN BIOMEDICAL OPTICS AND IMAGING
}

\section{Endoscopic Microscopy XII}

\author{
Guillermo J. Tearney \\ Thomas D. Wang \\ Editors
}

29-30 January 2017

San Francisco, California, United States

Sponsored and Published by

SPIE 
The papers included in this volume were part of the technical conference cited on the cover and title page. Papers were selected and subject to review by the editors and conference program committee. Some conference presentations may not be available for publication. The papers published in these proceedings reflect the work and thoughts of the authors and are published herein as submitted. The publisher is not responsible for the validity of the information or for any outcomes resulting from reliance thereon.

Please use the following format to cite material from these proceedings:

Author(s), "Title of Paper," in Endoscopic Microscopy XII, edited by Guillermo J. Tearney, Thomas D. Wang, Proceedings of SPIE Vol. 10040 (SPIE, Bellingham, WA, 2017) Seven-digit Article CID Number.

ISSN: 1605-7422

ISSN: 2410-9045 (electronic)

ISBN: 9781510605213

ISBN: 9781510605220 (electronic)

Published by

SPIE

P.O. Box 10, Bellingham, Washington 98227-0010 USA

Telephone +1 3606763290 (Pacific Time) · Fax +1 3606471445

SPIE.org

Copyright (C) 2017, Society of Photo-Optical Instrumentation Engineers.

Copying of material in this book for internal or personal use, or for the internal or personal use of specific clients, beyond the fair use provisions granted by the U.S. Copyright Law is authorized by SPIE subject to payment of copying fees. The Transactional Reporting Service base fee for this volume is $\$ 18.00$ per article (or portion thereof), which should be paid directly to the Copyright Clearance Center (CCC), 222 Rosewood Drive, Danvers, MA 01923. Payment may also be made electronically through CCC Online at copyright.com. Other copying for republication, resale, advertising or promotion, or any form of systematic or multiple reproduction of any material in this book is prohibited except with permission in writing from the publisher. The CCC fee code is 1605 $7422 / 17 / \$ 18.00$.

Printed in the United States of America.

Publication of record for individual papers is online in the SPIE Digital Library.

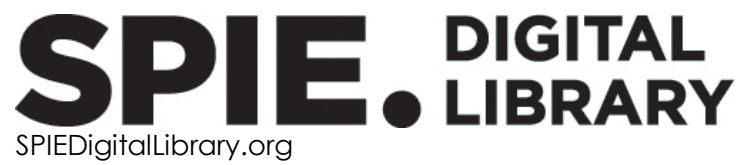

Paper Numbering: Proceedings of SPIE follow an e-First publication model, with papers published first online and then in print. Papers are published as they are submitted and meet publication criteria. A unique citation identifier (CID) number is assigned to each article at the time of the first publication. Utilization of CIDs allows articles to be fully citable as soon as they are published online, and connects the same identifier to all online, print, and electronic versions of the publication. SPIE uses a seven-digit CID article numbering system in which:

- The first five digits correspond to the SPIE volume number.

- The last two digits indicate publication order within the volume using a Base 36 numbering

system employing both numerals and letters. These two-number sets start with 00, 01, 02, 03, 04, $05,06,07,08,09,0 A, 0 B \ldots$. OZ, followed by 10-1Z, 20-2Z, etc.

The CID Number appears on each page of the manuscript. The complete citation is used on the first page, and an abbreviated version on subsequent pages. 


\title{
Contents
}

\author{
$\checkmark$ Authors \\ vii Conference Committee
}

\section{NEW TECHNIQUES}

1004006 Evaluation of computational endomicroscopy architectures for minimally invasive optical biopsy [10040-5]

1004007 Chip-on-the-tip ultra-compact flexible endoscopic epifluorescence video-microscope for in-vivo imaging in medical and biomedical fields [10040-6]

\section{SPECTROSCOPY/POLARIZATION}

1004008 Optical characterization and polarization calibration for rigid endoscopes [10040-7]

1004009 Minimally invasive optical biopsy for oximetry [10040-8]

10040 OA Spectral and lifetime endomicroscopic measurements using one and two-photon excitation [10040-9]

\section{TETHERED CAPSULE ENDOMICROSCOPY}

$10040 \mathrm{OH}$ Single lens system for forward-viewing navigation and scanning side-viewing optical coherence tomography [10040-36]

SPECTRAL ENCODING

10040 OM Ultraminiature video-rate forward-view spectrally encoded endoscopy with straight axis configuration [10040-20]

\section{OPTICAL COHERENCE TOMOGRAPHY}

10040 OP Miniature multimodal endoscopic probe based on double-clad fiber [10040-24] 
Proc. of SPIE Vol. $100401004001-4$

Downloaded From: https://www.spiedigitallibrary.org/conference-proceedings-of-spie on 26 Apr 2023 Terms of Use: https://www.spiedigitallibrary.org/terms-of-use 


\section{Authors}

Numbers in the index correspond to the last two digits of the seven-digit citation identifier (CID) article numbering system used in Proceedings of SPIE. The first five digits reflect the volume number. Base 36 numbering is employed for the last two digits and indicates the order of articles within the volume. Numbers start with 00, 01, 02, 03, 04, 05, 06, 07, 08, 09, 0A, 0B...0Z, followed by 10-1Z, 20-2Z, etc.

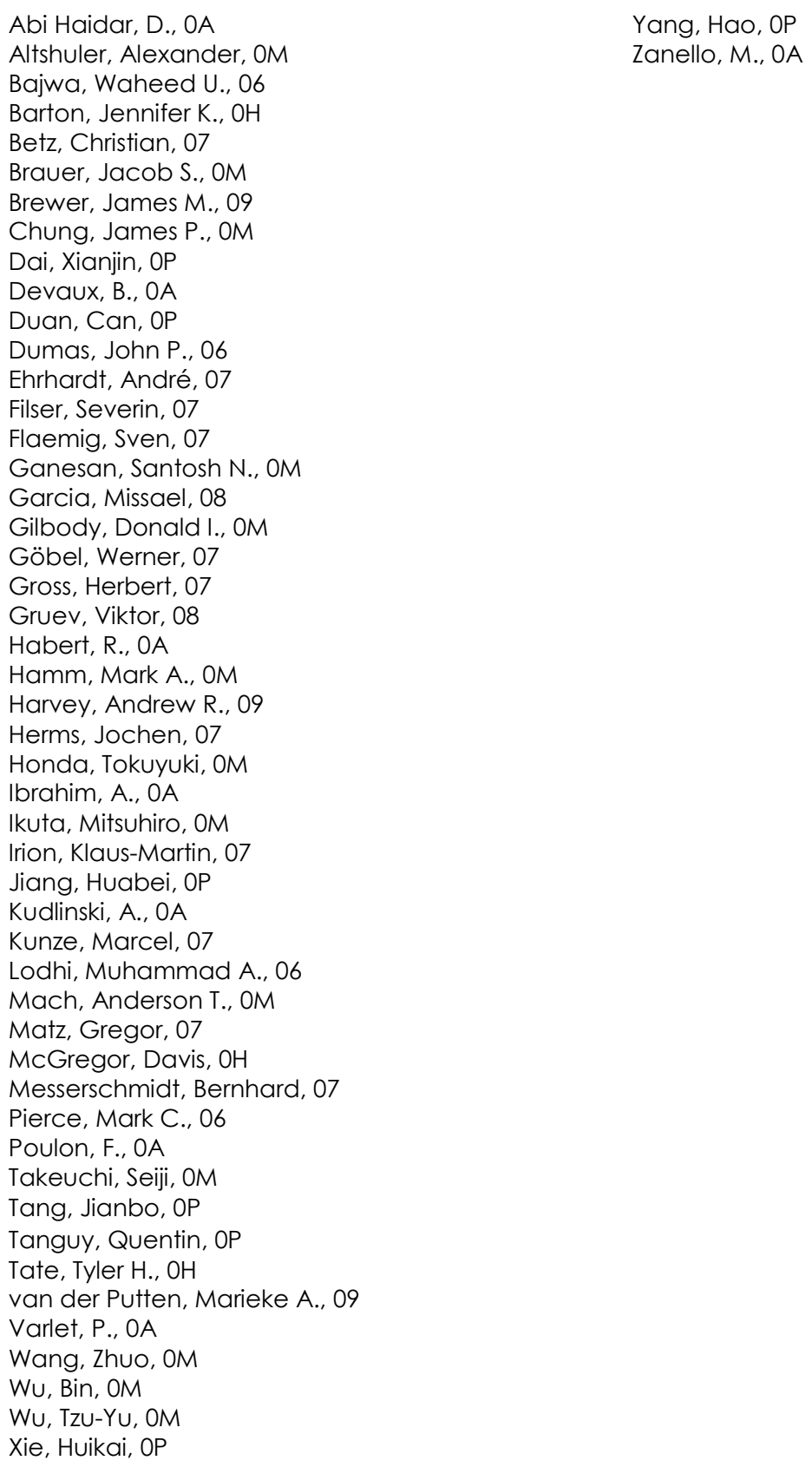

Yang, Hao, OP

Zanello, M., OA 
Proc. of SPIE Vol. $100401004001-6$

Downloaded From: https://www.spiedigitallibrary.org/conference-proceedings-of-spie on 26 Apr 2023 Terms of Use: https://www.spiedigitallibrary.org/terms-of-use 


\title{
Conference Committee
}

\author{
Symposium Chairs \\ James G. Fujimoto, Massachusetts Institute of Technology \\ (United States) \\ R. Rox Anderson, Wellman Center for Photomedicine, Massachusetts \\ General Hospital (United States) and Harvard School of Medicine \\ (United States)
}

Program Track Chair:

Brian Jet-Fei Wong, Beckman Laser Institute and Medical Clinic (United States)

\section{Conference Chairs}

Guillermo J. Tearney, Wellman Center for Photomedicine (United States)

Thomas D. Wang, University of Michigan (United States)

\section{Conference Program Committee}

David L. Dickensheets, Montana State University (United States)

Arthur F. Gmitro, The University of Arizona (United States)

Ralf Kiesslich, Johannes Gutenberg-Universität Mainz (Germany)

Francois Lacombe, Mauna Kea Technologies (France)

Stephen Lam, The BC Cancer Agency Research Center (Canada)

Hiroshi Mashimo, VA Boston Healthcare System (United States)

Kenzi Murakami, Olympus Corporation (Japan)

Norman S. Nishioka, Massachusetts General Hospital (United States)

Wibool Piyawattanametha, King Mongkut's Institute of Technology Ladkrabang (Thailand)

Mark J. Schnitzer, Stanford University School of Medicine (United States)

Peter T. C. So, Massachusetts Institute of Technology (United States)

Melissa J. Suter, Massachusetts General Hospital (United States)

Session Chairs

1 New Techniques

Thomas D. Wang, University of Michigan (United States) 
2 Spectroscopy/Polarization

Jennifer K. Barton, The University of Arizona (United States)

3 Tethered Capsule Endomicroscopy

Guillermo J. Tearney, Wellman Center for Photomedicine (United States)

$4 \quad$ Spectral Encoding

DongKyun Kang, Massachusetts General Hospital (United States)

5 Optical Coherence Tomography

Guillermo J. Tearney, Wellman Center for Photomedicine (United States)

$6 \quad$ Novel Imaging Probes

Francois Lacombe, Mauna Kea Technologies (France)

7 MEMS-based Endoscopic Imaging: Joint Session with Conferences 10040 and 10116

Wibool Piyawattanametha, King Mongkut's Institute of Technology Ladkrabang (Thailand) 